\title{
Uptake by neuroblastoma cells of glucosylceramide, glucosylceramide glucosidase, its stimulator protein, and phosphatidylserine
}

\author{
Subhash C. Datta, R. Michael Snider and Norman S. Radin* \\ Mental Health Research Institute, University of Michigan, Ann Arbor, MI 48109 (U.S.A.)
}

(Received March 6th, 1986)

Key words: Glucosylceramide hydrolysis; $\beta$-Glucosidase-stimulating protein; Enzyme uptake; Gaucher disease;
Phosphatidylserine stimulation effect; (Neuroblastoma cell)

Serum-free cultured neuroblastoma cells (clone NIE-115) have been shown to absorb emulsified glucosylceramide, glucosylceramide glucosidase, an activator protein for the enzyme, and phosphatidylserine from a synthetic medium. Uptake of the enzyme was augmented by phosphatidylserine, and vice versa. Uptake of the enzyme-lipid complex was further augmented by the activator protein. It appears likely that the activator forms a complex only with the enzyme-lipid complex, not with the individual components. Two uptake mechanisms for the enzyme seem to be involved, one of which (the complex with activator proteins and acidic lipid) is sensitive to mannosyl phosphate groups. Hydrolysis of absorbed glucosylceramide was slow unless the medium was supplemented with the acidic phospholipid or glucosidase. The most rapid disappearance of stored glycolipid took place when the ternary mixture was added to the cell medium, enzyme + activator protein + phosphatidylserine. These findings may be relevant to enzyme replacement therapy for Gaucher disease.

\section{Introduction}

Some genetic disorders characterized by low-efficiency enzymes can, in theory, be treated by injecting the normal enzyme. One must hope that most of the normal enzyme molecules will reach the required sites of action and survive long enough to eliminate accumulated substrate. The enzyme can be injected intravenously in the free form, as a complex with an antibody, or as an inclusion of a liposome or red cell ghost. Alternatively, it can be modified chemically to resist proteolytic degradation or enable it to enter cells via specific receptors. We describe a new system in which the

\footnotetext{
* To whom correspondence should be addressed at: Neuroscience Bldg., 1103 E. Huron, Ann Arbor, MI 48104-1687, U.S.A.
}

enzyme is bound noncovalently to its natural activators and then effectively taken up by cells in vitro.

The model system was developed with cultured neuroblastoma cells of murine origin (clone NIE115 ), grown under serum-free conditions. The enzyme studied was glucosylceramide (GlcCer) $\beta$-glucosidase (EC 3.2.1.45). This is the enzyme which occurs in defective form in individuals with Gaucher disease. A striking result of the genetic defect is a large accumulation of the substrate, a glucosphingolipid which is a precursor of several nonionic glycolipids and most of the gangliosides. Another striking aspect of the disorder is an accumulation of a family of activator proteins, called cohydrolase here. The activator proteins stimulate not only the glucosidase but also sphingomyelinase and galactosylceramide $\beta$-galactosidase [ $1-3]$.

Cohydrolase forms a complex with glucosidase, 
apparently in conjunction with an acidic phospholipid such as phosphatidylserine [4,5]. The complex exhibits a lowered $K_{\mathrm{m}}$ for its substrate as well as higher activity. Additional evidence for the formation of a ternary complex has come from density gradient centrifugation [6] and tests with an inactivator of the enzyme [7]. The acidic phospholipid itself also acts as a stimulator of the enzyme. Immobilized cohydrolase, attached to Sepharose 4B, binds the crude enzyme and affords significant purification [4]. This paper describes cellular uptake from the culture medium of the various substances involved.

\section{Materials and Methods}

\section{Chemicals}

Cohydrolase was isolated from bovine spleen [8] and stored at $4^{\circ} \mathrm{C}$ in buffer $\mathrm{A}(5 \mathrm{mM}$ phosphate ( $\mathrm{pH} \mathrm{7)/40} \mathrm{mM} \mathrm{NaCl}$ ) containing $0.02 \%$ $\mathrm{NaN}_{3}$. It was separated into two fractions, one that does not adhere to concanavalin A-Sepharose, and one that does bind and is eluted with $0.5 \mathrm{M} \mathrm{NaCl}$ and $0.5 \mathrm{M}$ methyl $\alpha$-mannoside in 5 $\mathrm{mM}(\mathrm{pH} \mathrm{7)}$ phosphate [9]. The latter form, after dialysis against buffer $A$, was used in most of these experiments.

Bovine brain phosphatidylserine (PS) was from Avanti Polar Lipids and phosphatidyl[U- $\left.{ }^{14} \mathrm{C}\right]-$ serine (dioleoyl) was from Amersham. A solution containing the former or a mixture of both (26 $\mathrm{cpm} / \mu \mathrm{g}$ ) was evaporated to dryness, sonicated in a cold bath with culture medium, and sterilized by filtration $(0.2 \mu \mathrm{m}$ Acrodisc assembly, Gelman Scientific). Sodium taurocholate was from Calbiochem Behring. Mannose 6-phosphate, methyl $\alpha$-mannoside, calf thymus DNA, glucose 6-phosphate, mannose, and concanavalin A-Sepharose CL-4B were from Sigma. A pentamannoside monophosphate was prepared from Halobacterium holstii $[10]$.

GlcCer (glucocerebroside), isolated from a Gaucher spleen, was dissolved in chloroform/ methanol with half its weight of Myrj 52 (a solid polyoxyethylene stearate with a hydrophile-lipophile balance rating of 16.9 from ICI Americas Inc., Wilmington, DE). The solution was evaporated to dryness and converted to a milky emulsion with $0.9 \% \mathrm{NaCl}$ or culture medium in an ultrasonic bath and sterilized by filtration just before addition to the medium. Some of the GlcCer was converted to [6- $\left.{ }^{3} \mathrm{H}\right]$ glucosylceramide [11].

Glucocerebrosidase was purified and delipidated from fresh human placenta by cholate extraction, ammonium sulfate precipitation, acid precipitation, butanol extraction, and affinity chromatography [12]. The enzyme was dialyzed against culture medium and concentrated under vacuum in the dialyzer just before use.

Cells

Murine neuroblastoma cells (clone N1E-115), passage 10-14, were grown in Dulbecco's modified Eagle's medium (GIBCO) supplemented (in amounts per liter) with $5 \mathrm{mg}$ of insulin, $20 \mathrm{nmol}$ progesterone, $0.1 \mathrm{mmol}$ putrescine, $30 \mathrm{nmol}$ selenite, $100 \mathrm{mg}$ of transferrin, $1.4 \mathrm{mg}$ of vitamin $\mathrm{B}-12,7 \mu \mathrm{g}$ of biotin, and $0.2 \mathrm{mg}$ of thioctic acid [13]. Subculture was achieved by inoculating $4 \cdot 10^{5}$ cells into $75 \mathrm{~cm}^{2}$ plastic tissue culture flasks containing $20 \mathrm{ml}$ of medium supplemented with $10 \%$ fetal bovine serum (GIBCO) without antibiotics. After $24 \mathrm{~h}$ of culture at $37^{\circ} \mathrm{C}$ in $10 \% \mathrm{CO}_{2} /$ humidified air, the medium was removed and replaced with $20 \mathrm{ml}$ of serum-free medium. The cells were fed on days 4 and 6 , and every day thereafter, by adding $10 \mathrm{ml}$ of fresh medium and removing 10 $\mathrm{ml}$ of medium.

After 6 days of culturc in scrum-frec medium, the medium was removed and replaced with $20 \mathrm{ml}$ of serum-free medium containing a small volume of test substance(s). Control and experimental flasks were incubated at $37^{\circ} \mathrm{C}$ in duplicate. At the end of the test incubation, the medium was removed and the cells were incubated for $5 \mathrm{~min}$ in Puck's D1 solution without trypsin [14]. They were then removed from the flasks, pooled, isolated hy centrifugation, suspended in phosphatebuffered saline ( $\mathrm{pH} \mathrm{7),} \mathrm{sonicated} \mathrm{on} \mathrm{ice,} \mathrm{and} \mathrm{as-}$ sayed.

Assays

Cohydrolase concentrations were measured with an immunoassay [15] with two portions of a cell extract, each purified with a size exclusion column and analyzed in duplicate. The uptake of cohydrolase was calculated from the formula,

To uptake $=100 \cdot\left(C_{\text {experimental }}-C_{\text {control }}\right) \cdot$ wt. protein $/$ wt. $\mathrm{CH}$ 
where $C$ is the concentration of cohydrolase in the control or experimental (cohydrolase-treated) cells, wt. protein is the weight of protein in the cohydrolase-treated cells, and wt. cohydrolase is the weight of cohydrolase added to the flasks. A similar calculation was used for the enzyme, with activity units instead of weights. This formula, which assumes that the endogenous level within the cells is unchanged by the uptake, corrects for the small differences in protein content between the different pooled groups.

Glucosidase activity was determined by a 30 min incubation in acetate $\mathrm{pH} 5.4$ and Triton $\mathrm{X}-100$, $0.5 \mathrm{mg} / \mathrm{ml}$, with either methylumbelliferyl-2- $\beta$-Dglucopyranoside or with $\left[{ }^{3} \mathrm{H}\right] \mathrm{GlcCer}$ as substrate. In the latter case, sodium taurocholate $(5 \mathrm{mg} / \mathrm{ml})$ was included [16]. One cerebroside or methylumbclliferyl-2- $\beta$-D-glucopyranoside unit of activity is the amount of enzyme which hydrolyzes 1 $\mathrm{nmol} / \mathrm{h}$ of substrate. Assays were run with two different amounts of sample to ensure the absence of interfering materials; the observed specific activities generally agreed within $4 \%$. The endogenous cohydrolase in the cells was too low to affect the measured glucosidase activities when methylumbelliferyl-2- $\beta$-D-glucopyranoside was the substrate. Tests of the enzyme assay system with labeled GlcCer as the substrate showed that the presence of $4 \mu \mathrm{g}$ PS in the $0.2 \mathrm{ml}$ of incubation medium or $50 \mathrm{pg}$ of cohydrolase with the phospholipid did not significantly change the observed activities.

Radioactivity was determined by scintillation counting of the wet cells or lipid extract in a water-miscible system. Analysis of the cell lipids was carried out by extracting cells with hexane/ isopropyl alcohol $3: 2$ and chromatographing the lipids on silica gel-coated TLC plates (E. Merck, No. 5763-7) with chloroform/methanol/water $24: 7: 1$. The water contained $1 \mathrm{M} \mathrm{NH}_{4} \mathrm{OH}$ and $\mathrm{KCl}, 2.5 \mathrm{mg} / \mathrm{ml}$.

Protein was determined by a colorimetric precipitation-Folin reaction with bovine serum albumin as standard [17] and DNA was determined by the diaminobenzoic acid fluorescence method [18].

\section{Results}

Occurrence of cohydrolase and glucosidase in the cells

The NIE-115 cells, cultured in normal (10\% fetal bovine serum) and in serum-free media, were found to contain cohydrolase (Table I), at a concentration similar to that found in mouse brain [15]. Its concentration, relative to total cell protein, did not change appreciably with time over the 7-day period studied. In contrast, the specific activity of glucosidase rose greatly. The two culture conditions employed yielded similar values and all later experiments were done in serum-free media with cells that had been grown in serum-free medium for 6 days.

\section{Uptake of cohydrolase by cells}

The cells were found to absorb cohydrolase from the medium, the amount increasing with time (Fig. 1). In this study, the activator preparation included the two types of protein - the kind which binds to concanavalin A-Sepharose and the kind which does not. The former type was $56 \%$ of the total. Calculating from the individual control flasks for each time point, one sees that the cells took up $9,13,14$, and $19 \%$ of the added factor by the end of $1,2,4$, and $6 \mathrm{~h}$, respectively. The reproducibility of the system is illustrated by the horizontal nature of the lower curve (control cells) and by the duplicate sample values in the figure.

Comparison of the two kinds of cohydrolase in a 6-h incubation showed that the concanavalin binding form was taken up more efficiently: $36 \%$ vs. 18\% (Table II). This form was used in all the later experiments. Significantly, we found that cohydrolase was not removed from the cells on washing, although some loosely bound protein was lost. This shows that the absorbed cohydrolase was firmly bound to the surface or internalized. In addition, the data show that endogenous cohydrolase did not leak out of the cells into the medium. The concentration of cohydrolase in the control cells, $1.72 \mathrm{ng} / \mathrm{ml}$ protein, was similar to the values found in other experiments (Table I and Fig. 1).

Since cohydrolase is a glycoprotein, we were interested in determining whether the uptake phenomenon involved a mannosyl phosphate receptor 
TABLE 1

GROWTH PROPERTIES OF NIE-115 CELLS WITH RESPECT TO TOTAL PROTEIN, GLUCOSYLCERAMIDE GLUCO. SIDASE, AND COHYDROLASE CONTENT

The protein values are derived from two culture dishes, each containing $20 \mathrm{ml}$ medium, and the other values are based on the total protein values. The glucosidase activities are in methylumbelliferyl-2- $\beta$-D-glucopyranoside units. Each measurement shown is a mean of duplicate assays.

\begin{tabular}{|c|c|c|c|c|c|c|c|c|}
\hline \multirow[t]{2}{*}{$\begin{array}{l}\text { Age } \\
\text { (days) }\end{array}$} & \multicolumn{2}{|l|}{$\begin{array}{l}\text { Protein } \\
\text { (mg) }\end{array}$} & \multicolumn{2}{|c|}{$\begin{array}{l}\text { Glucosidase } \\
\text { activity } \\
\text { (a) }(\mathrm{nmol} / \mathrm{h} \text { per } \mathrm{mg})\end{array}$} & \multicolumn{2}{|c|}{$\begin{array}{l}\text { Cohydrolase } \\
\text { concentration } \\
\text { (b) }(\mathrm{ng} / \mathrm{mg})\end{array}$} & \multicolumn{2}{|l|}{$\begin{array}{l}\text { Ratio } \\
\text { (a) } /(b)\end{array}$} \\
\hline & + serum & - serum & + serum & - serum & + serum & - serum & + serum & - serum \\
\hline 3 & 3.8 & 5.0 & 10 & 7 & 1.7 & 1.5 & 6 & 4 \\
\hline 4 & 5.7 & 5.9 & 15 & 14 & 1.6 & 1.6 & 9 & 9 \\
\hline 6 & 16 & 10.9 & 23 & 16 & 1.5 & 1.5 & 15 & 11 \\
\hline 7 & 24 & 25 & 25 & 22 & 1.8 & 1.6 & 14 & 13 \\
\hline 8 & 22 & 18 & 32 & 29 & 1.6 & 1.5 & 20 & 19 \\
\hline 10 & 28 & 24 & 38 & 33 & 1.7 & 1.5 & 22 & 21 \\
\hline
\end{tabular}

on the cell surface. When cells were incubated for $6 \mathrm{~h}$ with $2 \mathrm{mM}$ mannose 6-phosphate, almost complete blockage of cohydrolase uptake was obtained (upper part of Table III). Mannose phosphate alone (line 2) had little or no effect on the endogenous cell level of cohydrolase. The uptakc of cohydrolase from the normal medium was $49 \%$, based on the average of the two control groups (lines 1 and 2). This was reduced by $86 \%$ when mannose phosphate was included in the incubation.

Another experiment (lower part of Table III) showed that other carbohydrates also interfered with cohydrolase uptake. A pentamannoside

\section{TABLE II}

\section{UPTAKE OF TWO COHYDROLASE (CH) FORMS BY INCUBATED CELLS}

Conditions as in Table I. Two flasks were incubated under each condition for $6 \mathrm{~h}$ and the pooled media were saved for analysis. The cells from each dish were washed for $5 \mathrm{~min}$ at $37^{\circ} \mathrm{C}$ with $5 \mathrm{ml}$ of Puck's D1 solution without trypsin, pooled, then sonicated in $5 \mathrm{mM}$ phosphate (pH 7) containing $1 \mathrm{M} \mathrm{NaCl}$ and analyzed. The cells of group CH.ConA - were incubated with $13.5 \mathrm{ng}$ of non-binding cohydrolase in two flasks; group $\mathrm{CH}$.ConA + , with $15 \mathrm{ng}$ of concanavalin A-binding cohydrolase. The degree of variability in the cohydrolase assays is indicated in the duplicate values shown for cohydrolase in the cells.

\begin{tabular}{|c|c|c|c|c|}
\hline Cells & $\begin{array}{l}\text { Fraction } \\
\text { analyzed }\end{array}$ & $\begin{array}{l}\text { Protein } \\
\text { content } \\
(\mathbf{m g})\end{array}$ & $\begin{array}{l}\text { Cohydrolase } \\
\text { content } \\
\text { (ng) }\end{array}$ & $\begin{array}{l}\text { Cohydrolase } \\
\text { present } \\
\text { (\% of added } \mathrm{CH} \text { ) }\end{array}$ \\
\hline \multirow[t]{3}{*}{ Control } & medium & 12.0 & 0.0 & - \\
\hline & wash & 1.15 & 0.0 & \\
\hline & cells & 7.4 & $12.9,12.6$ & - \\
\hline \multirow[t]{3}{*}{ CH.ConA + } & medium & 12.0 & 7.08 & 47 \\
\hline & wash & 1.45 & 0.0 & \\
\hline & cells & 7.4 & $17.9,18.2$ & $36^{*}$ \\
\hline \multirow[t]{3}{*}{ CH.ConA - } & medium & 13.5 & 7.68 & 57 \\
\hline & wash & 1.45 & 0.0 & \\
\hline & cells & 7.5 & $15.2,14.9$ & $18^{*}$ \\
\hline
\end{tabular}

\footnotetext{
* These values have been corrected for the endogenous level of cohydrolase.
} 


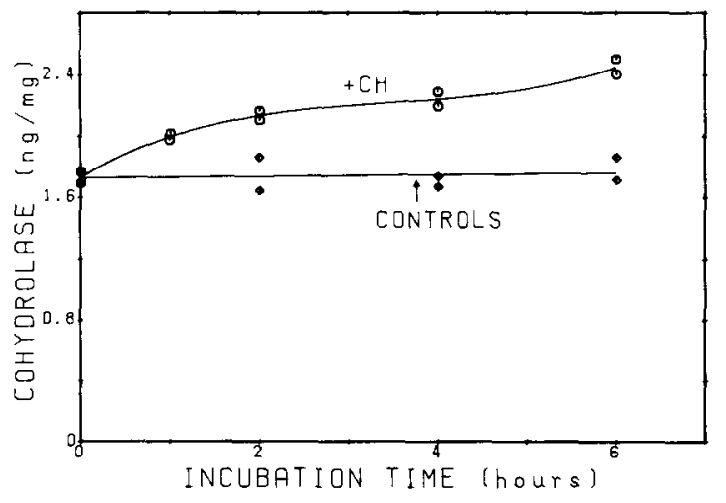

Fig. 1. Uptake of cohydrolase ( $\mathrm{CH}$ ) by neuroblastoma cells as a function of time. Each flask contained $7.5 \mathrm{ng}$ of mixed types of cohydrolase in $20 \mathrm{ml}$ of medium and the cells from two flasks werc pooled for assay. The lower curve shows the cohydrolase contents of control cells incubated without added cohydrolase.

monophosphate was quite effective, reducing cohydrolase uptake by $67 \%$ at a concentration of only $300 \mathrm{ng} / \mathrm{ml}$. Mannose itself $(10 \mathrm{mM})$ reduced cohydrolase uptake by $63 \%$ and $2 \mathrm{mM}$ glucose 6-phosphate also showed some blocking activity: $33 \%$.

\section{Effect of glucosidase on cohydrolase uptake}

Uptake of cohydrolase was not appreciably improved by adding glucosidase to the medium (Table IV). In this study, $7.5 \mathrm{ng}$ of cohydrolase were added to the $20 \mathrm{ml}$ of medium in each dish, giving an uptake of $49 \%$ in $6 \mathrm{~h}$. Including glucosidase (495 methylumbelliferyl-2- $\beta$-D-glucopyranoside units/flask) brought the uptake of cohydrolase to $54 \%$. The enzyme uptake, $24 \%$, was the same with or without cohydrolase. From these findings, it would appear that the two proteins do not interact in the absence of lipids. It may be noted that the amount of enzyme taken up was far greater than the endogenous level. The recovery of added enzyme in cells and medium was $74 \%$ with or without added cohydrolase.

In a similar experiment, with PS in the medium of all flasks but two $(20 \mu \mathrm{g} / \mathrm{ml})$, cohydrolasc uptake was $45 \%$ without enzyme and $40 \%$ with enzyme (Table V). However, the glucosidase uptake was definitely improved by cohydrolase, increasing from $31 \%$ without to $48 \%$ with cohydrolase. The latter observation can be interpreted to mean that cohydrolase does combine with the enzyme if PS is present, and that this complex is absorbed more efficiently than free enzyme. The

TABLE III

\section{EFFECT OF CARBOHYDRATES ON UPTAKE OF COHYDROLASE (CH)}

Conditions as in Methods section. Duplicate flasks containing cells were incubated $6 \mathrm{~h}$ with buffer alone, or with cohydrolase (375 $\mathrm{pg} / \mathrm{ml}$ ), or with a carbohydrate, or with both, then assayed for cohydrolase content of the cells. Some of the values in this table are shown as individual results of duplicate analyses. The uptake values for cohydrolase are based on the average cohydrolase content of all the controls. M-6- $P$, mannose 6-phosphate; (Man) $)_{5} P$, pentamannoside monophosphate; G-6- $P$, glucose 6-phosphate.

\begin{tabular}{|c|c|c|c|}
\hline Group & $\begin{array}{l}\text { Total protein } \\
(\mathrm{mg})\end{array}$ & $\begin{array}{l}\text { CH concentration } \\
\text { ( } \mathrm{ng} / \mathrm{mg} \text { protein) }\end{array}$ & $\begin{array}{l}\text { CH uptake } \\
(\%)\end{array}$ \\
\hline Control & $9.6,9.9$ & $1.73,1.79$ & - \\
\hline M-6- $P$ alone $(2 \mathrm{mM})$ & $9.6,9.9$ & $1.62,1.68$ & - \\
\hline Cohydrolase alone & $10.5,9.9$ & $2.49,2.38$ & 49 \\
\hline $\mathrm{CH}+\mathrm{M}-6-\mathrm{P}$ & $10.2,9.6$ & $1.82,1.82$ & 7 \\
\hline Control & 8.85 & $1.65,1.69$ & - \\
\hline $\mathrm{G}-6-P(2 \mathrm{mM})$ & 8.70 & $1.62,1.59$ & - \\
\hline$(\operatorname{Man})_{5} P$ & 8.63 & $1.63,1.60$ & - \\
\hline Mannose $(10 \mathrm{mM})$ & 9.38 & $1.56,1.59$ & - \\
\hline Cohydrolase alone & 9.08 & $2.42,2.39$ & 48 \\
\hline $\mathrm{CH}+\mathrm{G}-6-P$ & 8.70 & $2.20,2.13$ & 32 \\
\hline $\mathrm{CH}+(\mathrm{Man})_{5} P$ & 8.33 & $1.89,1.86$ & 14 \\
\hline $\mathrm{CH}+$ mannose & 8.33 & $1.97,1.89$ & 17 \\
\hline
\end{tabular}


TABLE IV

\section{INTERACTION BETWEEN COHYDROLASE AND GLUCOSIDASE}

Data are derived from two pooled dishes for each condition. Cohydrolase ( $125 \mu 1,60 \mathrm{pg} / \mu \mathrm{l}$ in buffer A) and glucosidase (275 $\mu \mathrm{l}$, 1.8 methylumbelliferyl-2- $\beta$-D-glucopyranoside units $/ \mu 1$ in medium) were added to each flask, as shown below. The medium for control cells was supplemented with the corresponding volume of buffer or medium. The values in parantheses are the percent of added cohydrolase $(\mathrm{CH})$ or enzyme taken up by the cells.

\begin{tabular}{|c|c|c|c|c|}
\hline \multirow[t]{2}{*}{ Group } & \multirow{2}{*}{$\begin{array}{l}\text { Total } \\
\text { protein } \\
(\mathrm{mg})\end{array}$} & \multirow{2}{*}{$\begin{array}{l}\text { Cohydrolase } \\
\text { concentration } \\
\text { (ng/mg protein) }\end{array}$} & \multicolumn{2}{|c|}{ Glucosidase activity ${ }^{*}(\mathrm{nmol} / \mathrm{h})$} \\
\hline & & & in cells & in medium \\
\hline Control & 10.5 & 1.73 & 25 & 24 \\
\hline$+\mathrm{CH}$ & 9.4 & $2.52(49 \%)$ & 24 & 56 \\
\hline Control & 12.3 & 1.79 & 23 & 13 \\
\hline tenzyme & 10.1 & 1.74 & $262(24 \%)$ & 475 \\
\hline Control & 11.0 & 1.71 & 20 & 14 \\
\hline$+\mathrm{CH}+$ enzyme & 12.2 & $2.38(54 \%)$ & $258(24 \%)$ & 474 \\
\hline Zero time & 11.7 & 1.60 & 23 & 11 \\
\hline
\end{tabular}

* Total activity.

failure to observe a corresponding increased uptake of cohydrolase in the presence of both PS and glucosidase can be attributed to the use of a relatively large molar excess of the activator (i.e., the increased uptake of cohydrolase could not bc measured accurately enough).

\section{Uptake of cerebroside glucosidase}

The above observation, that enzyme uptake was enhanced by cohydrolase in the presence of PS, was studied further. Control cells were incubated for $6 \mathrm{~h}$ without added enzyme, with PS alone (20 $\mu \mathrm{g} / \mathrm{ml})$, or with cohydrolase alone $(375 \mathrm{pg} / \mathrm{ml})$, or with both. This yielded cells having unchanged enzyme specific activity (top four lines, Table VI). Incubation with exogenous glucosidase alone (14 cerebroside units $/ \mathrm{ml}$ ) resulted in $24 \%$ of the added enzyme being taken up. As noted before, this represented a large increase above the endogenous level. Inclusion of PS with the enzyme produced a markedly higher uptake (37\%). Inclusion of cohydrolase with the enzyme, without phospholi-

\section{TABLE V}

\section{INTERACTION BETWEEN COHYDROLASE AND GLUCOSIDASE IN THE PRESENCE OF PHOSPHATIDYLSERINE}

Conditions as in Table IV, except that all flasks (except the last set) contained $20 \mu \mathrm{g} / \mathrm{ml}$ of PS. The values in parentheses are the percent of added cohydrolase $(\mathrm{CH})$ or enzyme taken up by the cells.

\begin{tabular}{|c|c|c|c|c|}
\hline \multirow[t]{2}{*}{ Group } & \multirow{2}{*}{$\begin{array}{l}\text { Total } \\
\text { protein } \\
(\mathrm{mg})\end{array}$} & \multirow{2}{*}{$\begin{array}{l}\text { Cohydrolase } \\
\text { concentration } \\
\text { (ng/mg protein) }\end{array}$} & \multicolumn{2}{|c|}{ Glucosidase activity ${ }^{*}(\mathrm{nmol} / \mathrm{h})$} \\
\hline & & & in cells & in medium \\
\hline Control & 6.8 & 1.44 & 38 & 15 \\
\hline$+\mathrm{CH}$ & 7.7 & $2.31(45 \%)$ & 41 & 29 \\
\hline Control & 8.5 & 1.45 & 40 & 21 \\
\hline + enzyme & 7.4 & 1.45 & $349(31 \%)$ & 371 \\
\hline Control & 7.1 & 1.51 & 37 & 49 \\
\hline$+\mathrm{CH}+$ enzyme & 6.8 & $2.39(40 \%)$ & $515(48 \%)$ & 264 \\
\hline No PS control & 6.6 & 1.38 & 34 & 18 \\
\hline
\end{tabular}

* Total activity. 
TABLE VI

UPTAKE OF GLUCOSYLCERAMIDE GLUCOSIDASE FROM CULTURE MEDIA AUGMENTED WITH COHYDROLASE AND PHOSPHATIDYLSERINE

The initial enzyme concentration was 14 cerebroside units per $\mathrm{ml}$ medium, the cohydrolase $(\mathrm{CH})$ concentration was $375 \mathrm{pg} / \mathrm{ml}$, and the PS concentration was $20 \mu \mathrm{g} / \mathrm{ml}$. The uptake percentage was corrected for the endogenous cellular enzyme in the control cells.

\begin{tabular}{|c|c|c|c|c|}
\hline \multirow[t]{2}{*}{ Medium } & \multirow{2}{*}{$\begin{array}{l}\text { Total protein } \\
(\mathrm{mg})\end{array}$} & \multicolumn{2}{|c|}{ Glucosidase activity $(\mathrm{nmol} / \mathrm{h})$} & \multirow{2}{*}{$\begin{array}{l}\text { Uptake of enzyme } \\
\text { ( } \% \text { of added } \\
\text { amount) }\end{array}$} \\
\hline & & in cells & in medium & \\
\hline Standard medium & 10.4 & 74 & 45 & - \\
\hline$+\mathbf{P S}$ & 10.6 & 78 & 45 & - \\
\hline$+\mathrm{CH}$ & 10.2 & 78 & 39 & - \\
\hline$+\mathrm{CH}+\mathrm{PS}$ & 11.0 & 75 & 41 & - \\
\hline Enzyme medium & 10.6 & 209 & 287 & 24 \\
\hline$+\mathrm{PS}$ & 10.1 & 285 & 180 & 37 \\
\hline$+\mathrm{CH}$ & 10.9 & 235 & 278 & 28 \\
\hline$+\mathrm{CH}+\mathrm{PS}$ & 10.6 & 368 & 146 & 53 \\
\hline
\end{tabular}

* Total activity.

pid, had little effect on the enzyme uptake (28\% uptake), as noted in Table IV. When all three components were added, a further enhancement was seen: $53 \%$ of the enzyme was taken up.

An uptake experiment like the above was run with the use of methylumbelliferyl-2- $\beta$-D-glucopyranoside in the enzyme assay system. The cells were incubated for $6 \mathrm{~h}$ with 17 methylumbelliferyl-2- $\beta$-D-glucopyranoside units of glucosidase per ml. Here the fractions of enzyme taken up under the four conditions were 21,34 (+PS), 25 $(+\mathrm{CH})$, and $53 \%$ (+ PS + cohydrolase). The specific activity of the enzyme in the last set of cells was 10-times that in the untreated cells. The recovery of added enzyme in cells + medium was $62-72 \%$, with and without activators, so one cannot attribute the increases in enzyme uptake to protection by PS or cohydrolase against enzyme inactivation.

A time comparison of the enzyme uptake in the presence of PS, 3 vs. $6 \mathrm{~h}$ of incubation, showed that most of the uptake was complete within $3 \mathrm{~h}$, with or without added cohydrolase: $28-30 \%$ uptake without the activator, $45-50 \%$ with the activator. Doubling or tripling the cohydrolase concentration in the medium did not increase the enzyme uptake or recovery from the dishes. From this observation, it would appear that we used a large molar equivalent excess of cohydrolase, com- pared to the enzyme. The same conclusion was drawn before from the data of Table IV.

In a test of carbohydrate interference, the uptake of glucosidase was studied as above, in the presence of $20 \mu \mathrm{g} / \mathrm{ml}$ of PS. This resulted in absorption of $31 \%$ of the added enzyme. The amount of uptake was unaffected by the presence of $1 \mathrm{mM}$ mannose 6-phosphate or the pentamannoside monophosphate $(0.3 \mu \mathrm{g} / \mathrm{ml})$. Evidently the enzyme-PS complex is not absorbed by neuroblastoma cells via a mannosyl phosphate receptor. This is in agreement with the report that this enzyme is absorbed by human fibroblasts by a non-mannosyl phosphate mechanism [19].

When, in the same experiment, glucosidase uptake was enhanced by inclusion of both PS and cohydrolase in the medium, the uptake of enzyme was $54 \%$ of the amount added and both mannose derivatives blocked the enhancement, bringing it back to 32 and $30 \%$, respectively. It seems likely from these observations that part of the enzyme (31\%) entered the cells by one mechanism and that the other portion $(54-31=23 \%)$ entered the cells by forming a complex with cohydrolase (and PS) which entered by the same mechanism responsible for cohydrolase uptake.

A comparison of different PS concentrations for their ability to enhance glucosidase uptakc showed that the enhancement was maximal at PS 
concentrations above $50 \mu \mathrm{g} / \mathrm{ml}$ in the medium (Fig. 2). Recoveries of enzyme in cells and media were $83-87 \%$, so it is evident that the enhancement by PS was not the result of improved recovery.

\section{Uptake of labeled phosphatidylserine}

When the medium contained only radioactive PS $(10 \mu \mathrm{g} / \mathrm{ml})$ for $6 \mathrm{~h}$, less than $1 \%$ of the lipid was taken up by the cells. When 700 methylumbelliferyl-2- $\beta$-D-glucopyranoside units of enzyme were included in the $40 \mathrm{ml}$ of medium, much more phospholipid was absorbed (9\%). The uptake was proportional to the concentration of lipid, rising to as high as $35 \%$ of the added lipid (lower curve of Fig 3).

When cohydrolase $(375 \mathrm{pg} / \mathrm{ml})$ was added to the medium together with glucosidase, the uptake of PS was enhanced even further (upper curve of Fig. 3). The recovery of added lipid in cells and medium was $78-91 \%$, unaffected by the presence or absence of the two proteins.

\section{Uptake of glucosylceramide and its degradation}

An important question is whether the glucosidase taken up by the cells reached a subcellular

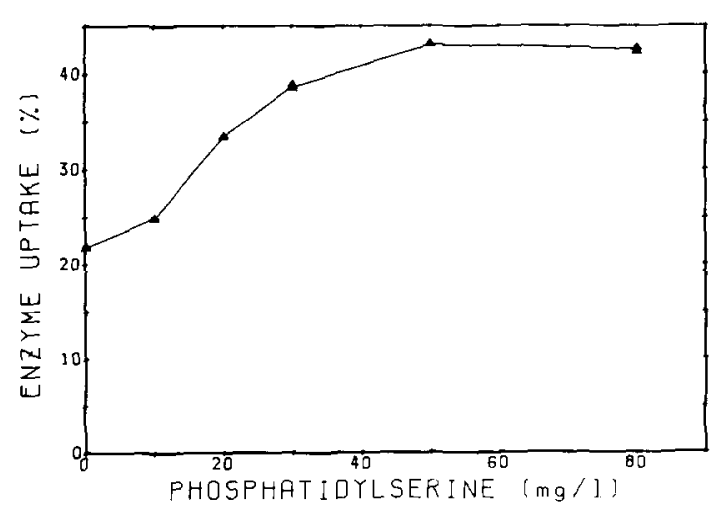

Fig. 2. Dependence of glucocerebrosidase uptake (percent of enzyme added to flasks) on concentration of phosphatidylserine in the medium. Two flasks containing 607 cerebroside units were incubated for $6 \mathrm{~h}$ with differing concentrations of PS. The enzyme uptake was calculated from the activity in the cells and the activity added. The duplicate values are too close to distinguish except for the 30 and $80 \mu \mathrm{g}$ points. The total cell protein in the two flasks at each time point was $6.0-6.2 \mathrm{mg}$.

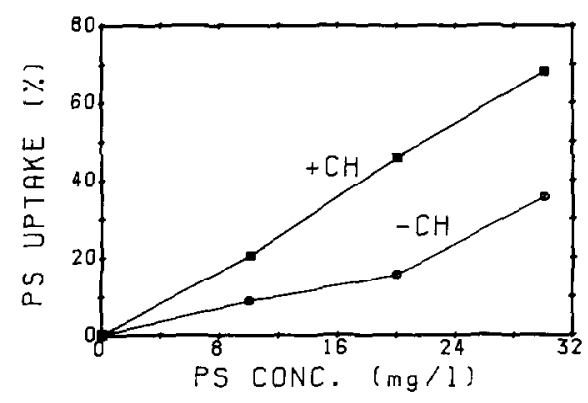

Fig. 3. Dependence of phosphatidylserine uptake (cpm in cells from two flasks) on the concentration of PS in the medium and the presence or absence of cohydrolase. Each flask contained 350 methylumbelliferyl-2- $\beta$-D-glucopyranoside units of glucosidase; half the flasks (upper curve) contained $375 \mathrm{pg} / \mathrm{ml}$ of cohydrolase. Note that the tick marks on the $x$ axis are 4 units apart.

location that is useful for the accelerated hydrolysis of GlcCer. It was first necessary to produce a model version of Gaucher disease in the cells. This has been achieved readily in intact mice by injection of a GlcCer glucosidase inactivator, conduritol $\mathrm{B}$ epoxide [20,21], or an emulsion of GlcCer glucosidase in the nonionic detergent, Myrj 52 [21]. The neuroblastoma cells were first examined with the detergent alone to make sure it was not highly toxic. A concentration of $0.1 \mathrm{mg} / \mathrm{ml} \mathrm{Myrj}$ showed no visible signs of toxicity after $24 \mathrm{~h}$, but $0.3 \mathrm{mg} / \mathrm{ml}$ produced some floating dead cells and all cells were killed by $1 \mathrm{mg} / \mathrm{ml}$ Myrj.

An emulsion was prepared with $25 \mu \mathrm{g}$ GlcCer and $12.5 \mu \mathrm{g}$ Myrj per $\mathrm{ml}$ of medium, and incubated with cells for $24 \mathrm{~h}$. The cells were washed and the lipids were examined by TI.C and charring. It was apparent that the cerebroside, normally not detectable at the level examined, had become a major lipid component of the cells. Maintenance of washed cells in fresh medium for 2 or 5 days did not result in significant loss of cerebroside. A similar failure to hydrolyze exogenous labeled GlcCer by human cultured fibroblasts has been observed [22]. While the GlcCer concentration used in our experiment was higher than the observed $20 \mu \mathrm{g} / \mathrm{ml}$ limit for nontoxicity in macrophage cultures [23], there was no sign of toxicity in our cells, as judged visually and by constancy of protein and DNA contents per culture (Table VII).

To increase the sensitivity of the cells to exoge- 
TABLE VII

EVALUATION OF CELLS FOR PROTEIN AND DNA CONTENT AFTER TAKING UP GLUCOCEREBROSIDE AND PHOSPHATIDYLSERINE

Cells in two flasks were incubated for $24 \mathrm{~h}$ with an emulsion of GleCer $(25 \mu \mathrm{g} / \mathrm{ml})$ and Myrj 52 , then washed and incubated further in serum-free medium. An additional set (lower part of table) was incubated with an emulsion of GlcCer $/ \mathrm{Myrj}$ and PS (10 $\mu \mathrm{g} / \mathrm{ml}$ ).

\begin{tabular}{|c|c|c|c|c|}
\hline $\begin{array}{l}\text { Incubation } \\
\text { medium }\end{array}$ & $\begin{array}{l}\text { Post-uptake period } \\
\text { (days) }\end{array}$ & $\begin{array}{l}\text { Total protein } \\
(\mathrm{mg})\end{array}$ & $\begin{array}{l}\text { Total DNA } \\
(\mu \mathrm{g})\end{array}$ & DNA/protein \\
\hline \multirow[t]{3}{*}{ GlcCer/Myrj } & 0 & 17.5 & 148 & 8.4 \\
\hline & 2 & 18.0 & 150 & 8.3 \\
\hline & 5 & 16.7 & 153 & 9.1 \\
\hline \multirow[t]{3}{*}{ GlcCer/Myrj + PS } & 0 & 16.6 & 148 & 8.9 \\
\hline & 2 & 17.1 & 152 & 8.9 \\
\hline & 5 & 16.5 & 150 & 9.1 \\
\hline Control cells (no lipid) & & 15.8 & 149 & 9.4 \\
\hline
\end{tabular}

nous materials, we repeated the experiment with lower concentrations of GlcCer $(5 \mu \mathrm{g} / \mathrm{ml})$. The resultant GlcCer spot on the TLC plate was fainter than before, but nevertheless quite distinct. At this level too there was little or no detectable disappearance of the glycolipid over a 5-day period. Phosphatidylserine $(5 \mu \mathrm{g} / \mathrm{ml})$, added with the GlcCer, was also absorbed but the elevation in cellular PS level was found to disappear after 2 days. The PS was clearly effective in speeding the disappearance of GlcCer. Our observations are consistent with the report that an emulsion of GlcCer with PS, injected intravenously into rats, resulted in uptake of the cerebroside by liver and spleen and its subsequent rapid disappearance [24].

The ability of exogenous glucosidase, cohydrolase, and PS to speed the disappearance of GlcCer from the model Gaucher cells was tested under the same conditions. Cells were loaded with cerebroside by a 24 -h incubation with emulsified GlcCer, $5 \mu \mathrm{g} / \mathrm{ml}$. TLC of the lipids (Fig. 4) showed again that a distinct amount of cerebroside had entered the cells (lane B vs. control cells, lane A) and that most of the cerebroside was still present after $24 \mathrm{~h}$ of exposure to stock medium (lane C vs. B). Cells which were exposed to glucosidase (550 cerebroside units) for $24 \mathrm{~h}$ showed a distinct decrease in cerebroside content (D vs. C). Exposure to PS alone, $5 \mu \mathrm{g} / \mathrm{ml}$, produced an even more effective disappearance of the lipid ( $E$ vs. D) and the combination of enzyme and PS was more effective than either alone ( $F$ vs. D or E). Glucosidase with cohydrolase $(375 \mathrm{pg} / \mathrm{ml})$ was not more effective than glucosidase alone ( $G$ vs. D), an observation to be expected from the previous data. The stron-

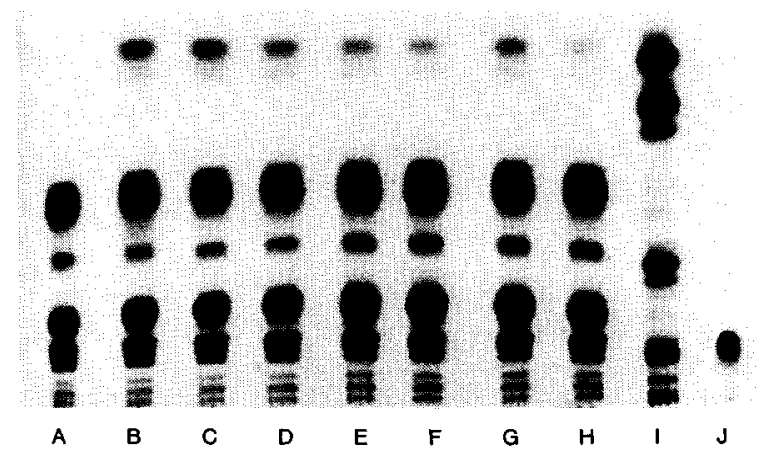

Fig. 4. Thin-layer plate showing neuroblastoma lipids, developed with chloroform/methanol/aqucous $\mathrm{KCl}$ in ammonium hydroxide. The highest spot is due to GlcCer. Each lane was derived from $1 / 30$ th of the lipids extracted from two flasks of cells. Lane $A$ is from cells treated only with stock medium; lanes $\mathrm{B}-\mathrm{H}$ are from cells which had been loaded with glucocerebroside for $24 \mathrm{~h}$, then washed with fresh medium and treated for another $24 \mathrm{~h}$ with various media. Lane B: cells extracted immediately after washing, showing the accumulated glucolipid. Lane C: cells exposed only to stock medium for 24 h, showing only slight disappearance of glucolipid. Lane D: exposed $24 \mathrm{~h}$ to medium augmented with glucosidase. $\mathrm{E}$ : exposed $24 \mathrm{~h}$ to PS medium. F: exposed to glucosidase + PS. $\mathrm{G}$ : glucosidase + cohydrolase. $\mathrm{H}$ : exposed to all three, glucosidase + PS + cohydrolase. Standards in lane I: three families of galactosylceramide at the top, sulfatide at the center, sphingomyelin near the bottom . Lane J: phosphatidylserine, a little faster moving than sphingomyelin on this plate. The darkest spot in the cell lipids is phosphatidylethanolamine and the next darkest is phosphatidylcholine. 
gest effect was produced by a mixture of the three, enzyme + cohydrolase + phospholipid, which produced almost complete disappearance of the stored glucolipid (lane $\mathrm{H}$ ).

In a similar experiment, the effect of PS plus cohydrolase (without added enzyme) was tested. The presence of labeled PS during the second $24 \mathrm{~h}$ incubation period $(9500 \mathrm{cpm}$ in each pair of culture dishes) was found to stimulate the disappearance of the glycolipid, as noted before. The presence of cohydrolase alone had little or no effect on the amount of GlcCer remaining in the cells, and cohydrolase did not enhance the effect of PS.

The amounts of radioactivity found in the cells were 879 and $723 \mathrm{cpm}$ (about 8\%), with and without added cohydrolase, respectively. Only a very small proportion of the absorbed labeled serine in the phospholipid was found in other cell components after the 24-h period. This makes it unlikely that the effect of PS was due to conversion to other substances.

A repetition of the experiment shown in Fig. 4 was made with labeled GlcCer to place the observations on a more precise basis and to prove that the stimulation of GlcCer disappearance was

\section{TABLE VIII}

\section{DISAPPEARANCE OF STORED GLUCOCEREBROSIDE} FROM NEUROBLASTOMA CELLS

Two dishes of cells were preloaded with GlcCer $(100 \mathrm{cpm} / \mu \mathrm{g})$ for $24 \mathrm{~h}$, washed with fresh medium, then incubated for $24 \mathrm{~h}$ with medium containing one or more additions. The lipids in the cells were extracted and the GlcCer was isolated by silica gel chromatography. The decrcase in cellular GleCer was calculated by comparison with the radioactivity of GlcCer in cells that were not incubated for the second $24 \mathrm{~h}$ period. $\mathrm{CH}$, cohydrolase.

\begin{tabular}{lc}
\hline Addition & $\begin{array}{l}\text { GlcCer decrease } \\
\text { (\% of control) }\end{array}$ \\
\hline None & 2 \\
Glucosidase & 22 \\
Phosphatidylserine & 38 \\
Cohydrolase & 11 \\
Glucosidase + PS & 52 \\
Glucosidase + CH & 27 \\
Cohydrolase + PS & 24 \\
Glucosidase + PS + CH & 74 \\
\hline
\end{tabular}

due to hydrolysis rather than enhanced addition of sugar moieties. The control cells (Table VIII) took up 93 out of $200 \mu \mathrm{g}$ of GlcCer added. Cohydrolase produced a small but measurable stimulation of GlcCer disappearance, which had not been detected in the previous visual estimation experiments. Otherwise, the results were much like those observed in Fig. 4. An important finding was that the polar lipids, eluted from the silica gel columns with chloroform/methanol/water 10 : $10: 1$, contained only a very small amount of radioactivity (3\% or less). Moreover, the ganglioside fraction, obtained by partitioning the total lipids between chloroform, methanol, and water [25], also contained very little activity (3\% or less). These observations show that the decreased activity in the cells treated with $\mathrm{CH}+\mathrm{PS}+$ glucosidase was not the result of enhanced synthetic activity (to form oligosaccharide ceramides).

\section{Discussion}

Our observations are consistent with previously published evidence indicating that glucosidase forms a complex with PS [4-7]. We found, by enzyme assay and radioactivity monitoring (Table VI and Figs. 2 and 3), that each of these substances enhanced the uptake of the other. The complex of the two substances, once they were absorbed by the cells, was effective in stimulating the hydrolysis of previously absorbed GlcCer (Table VIII and Fig. 4). Phosphatidylserine alone also stimulated GlcCer hydrolysis, evidently interacting within the cells with the endogenous glucosidase, which was not in a fully activated state. Cultured fibroblasts and lymphocytes from some Gaucher patients have also been shown to respond similarly to PS added in vitro [26,27]. It may be noted that our assay for glucosidase in vitro (Table VI, line 6) did not show the stimulation effect, apparently because the absorbed PS - $0.8 \mu \mathrm{g}$ in the assay system - dissociated by dilution in the assay procedure.

That cohydrolase and PS do not interact with one another was indicated by the failure of either substance to enhance the uptake of the other. This too agrees with previous work [5,6], which showed that cohydrolase had little stimulatory effect on glucosidase in vitro unless an acidic lipid was 
present. However, cohydrolase did enhance PS uplake by the cells when the latter was bound to glucosidase. From Table VIII, lines 1 and 4 , it would appear that the endogenous glucosidase in the neuroblastoma cells was almost fully saturated with cohydrolase.

The mechanism of glucosidase uptake remains obscure and we know only that PS and PS + cohydrolase improve its absorption. Perhaps the enzyme, without added acidic lipid, binds to acidic lipids in the plasma membrane and the complex is then incorporated into a type of lysosome. The complex of enzyme and lipid, presented to the cells exogenously, may contain the enzyme as part of a micellar structure dominated by the lipid. This micelle may enter the cells by permeating the plasma membrane. Cohydrolase, on the other hand, secms to be absorbed by a sugar-sensitive receptor region (Table III). The ternary complex formed between cohydrolase, PS and glucosidase appears to be absorbed by this mechanism, since its uptake could be blocked by mannose phosphate and pentamannosyl phosphate despite the possible presence of micellar PS. The pentasaccharide has been found to strongly inhibit glucuronidase uptake, apparently through its competition for mannosyl phosphate receptors [10].

We found by direct measurement that PS and cohydrolase together improved the ability of cells to take up GlcCer glucosidase and, importantly, that the enzyme taken up in this manner was in a cellular location that allowed it to act on its stored substrate. This observation may be of value in the treatment of Gaucher disease. Administration of the ternary complex would utilize chemically unmodified enzyme and therefore may be safer than the chemical derivatization approach, in which the enzyme is attached chemically to an oligosaccharide or glycoprotein and might thus produce immune reactions.

The injection of Gaucher patients with highly purified glucosidase has not yet proved to be effective enough to reverse the symptoms $[28,29]$. One could hypothesize that there is already a great surplus of cohydrolase in these patients and that the injected enzyme ought to reach the cohydrolase and become activated. Apparently this does not happen. One possible explanation is that the amount of available acidic phospholipid, which is needed for forming the active ternary complex, is inadequate. It is possible, therefore, that glucosidase should first be combined with PS before injection.

Experiments with mice, in which the level of liver GlcCer rose as the result of injecting emulsified GlcCer or a glucosidase inactivator, showed that the animals responded with a rapid increase in the level of liver cohydrolase [21]. This response, which mimicked that of Gaucher patients, suggests that the activator protein is elevated by the cells in order to stimulate the endogenous glucosidase and normalize the GlcCer level. In view of the known role of acidic phospholipids in activating the glucosidase, and our uptake findings, it is possible that the cellular level of PS is another important controlling factor.

Phosphatidylserine may also play a specific role in cellular uptake mechanisms. It has been shown that red cells coated with this lipid are taken up by the reticuloendothelial system much more effectively [30]. It also aids the uptake of sterols when mixed with sterol carrier protein $[31,32]$, the uptake of $\gamma$-aminobutyric acid by synaptosomes [33], and the uptake of galactosylceramide and lactosylceramide by cultured fibroblasts [34]. In this last study, the acidic lipid was found to accelerate the hydrolysis of the glycolipids, a finding like ours.

Since cells and intact animals [21] readily absorb GlcCer, when emulsified with Myrj 52, it becomes possible to induce a model form of Gaucher disease in vitro and in vivo. This may ease the problem of testing chemotherapeutic treatments for the disorder. While the cell type used in the present study is derived from brain, the symptoms of Gaucher disease are derived primarily from reticuloendothelial cells, which could be studied by this approach.

\section{Acknowledgements}

We thank Inez Mason and Linda G. O'Dell for technical assistance. Dr. G.W. Jourdian kindly furnished the phosphopentamannose. Supported in part by National Institutes of Health grants NS-03192, NS-15413 and NS-20920. N.S.R. is a recipient of the N.I.H. Jacob Javits Neuroscience Investigator Award. 


\section{References}

1 Ho, M.W. and O'Brien, J.S. (1971) Proc. Natl. Acad. Sci. USA $68,2810-2813$

2 Wenger, D.A., Sattler, M. and Roth, S. (1982) Biochim Biophys. Acta 712, 639-649

3 Poulos, A., Ranieri, E., Shankaran, P. and Callahan, J.W. (1984) Biochim. Biophys. Acta 793, 141-148

4 Berent, S.L. and Radin, N.S. (1981) Biochim. Biophys. Acta $664,572-582$

5 Ho, M.W. and Light, N.D. (1973) Biochem. J. 136, 821-823

6 Prence, E., Chakravorti, S., Basu, A., Clark, L.S., Glew, R.H. and Chambers, J.A. (1985) Arch. Biochem. Biophys. 236, 98-109

7 Basu, A., Glew, R.H., Daniels, L.B. and Clark, L.S. (1984) J. Biol. Chem. 259, 1714-1719

8 Radin, N.S. and Berent, S.L. (1982) Methods Enzymol, 83, 596-603

9 Iyer, S.S., Berent, S.L. and Radin, N.S. (1983) Biochim. Biophys. Acta 748, 1-7

10 Fischer, H.D., Natowicz, M., Sly, W.S. and Bretthauer, R.K. (1980) J. Cell Biol, 84, 77-86

11 McMaster, M.C., Jr. and Radin, N.S. (1977) J. Labelled Comp. Radiopharm. 13, 353-357

12 Grabowski, G.A. and Dagan, A. (1984) Anal. Biochem. 141, 267-269

13 Carlson, J., Smith, A. and Richelson, E. (1982) In Vitro 18, $175-178$

14 Wilson, S.H., Schrier, B.K., Farber, J.L., Thompson, E.J., Rosenberg, R.N., Blume, A.J. and Nirenberg, M.W. (1972) J. Biol. Chem. 247, 3159-3169

15 Datta, S.C. and Radin, N.S. (1984) Anal. Biochem. 142 196-203

16 Hara, A. and Radin, N.S. (1979) Biochim. Biophys. Acta $582,412-422$

17 Peterson, G.L. (1977) Anal. Biochem. 83, 346-356

18 Fiszer-Szafarz, B., Szafarz, D. and DeMurillo, A.G. (1981) Anal. Biochem. 110, 165-170
19 Murray, G.J., Jonsson, L.V., Sorrell, S.H., Ginns, E.I., Tager, J.M. and Barranger, J.A. (1985) Fed. Proc. 44, 709

20 Kanfer, J.N., Legler, G., Sullivan, J., Raghavan, S.S. and Mumford, R.A. (1975) Biochem. Biophys. Res. Commun. 67, 85-90

21 Datta, S.C. and Radin, N.S. (1985) Fed. Proc. 44, 1090

22 Saito, M. and Rosenberg, A. (1985) J. Biol. Chem. 260, 2295-2300

23 Gery, I., Zigler, J.S., Jr., Brady, R.O. and Barranger, J.A. (1981) J. Clin. Invest. 68, 1182-1189

24 Pentchev, P.G., Gal, A.E., Wong, R., Morrone, S., Neumeyer, B., Massey, J., Kanter, R., Sawitsky, A. and Brady, R.O. (1981) Biochim. Biophys. Acta 665, 615-618

25 Folch, J., Lees, M. and Sloane-Stanley, G.H. (1957) J. Biol. Chem. 226, 497-509

26 Gatt, S., Dinur, T., Osiecki, K., Desnick, R.J. and Grabowski, G.A. (1985) Enzyme 33, 109-119

27 Choy, F.Y.M. (1984) Human Genet. 67, 432-436

28 Brady, R.O. and Barranger, J.A. (1983) in The Metabolic Basis of Inherited Disease (Stanbury, J.B., Wyngaarden, J.B., Fredrickson, D.S., Goldstein, J.L. and Brown, M.S., eds.), 5th Edn., pp. 842-856, McGraw-Hill, New York

29 Beutler, E., Dale, G.L. and Kuhl, W. (1980) in Enzyme Therapy in Genetic Diseases Vol. 2 (Desnick, R.J., Paul, N.W. and Dickman, F., eds.), pp. 369-381, Alan R. Liss, New York

30 Schroil, A.J., Madsen, J.W. and Tanaka, Y. (1985) J. Biol. Chem. 260, 5131-5138

31 Caras, I.W., Friedlander, E.J. and Bloch, K. (1980) J. Biol. Chem. 255, 3575-3580

32 Chin, J. and Bloch, K. (1984) J. Biol. Chem. 259 , 11735-11738

33 Chweh, A.Y. and Leslie, S.W. (1982) J. Neurochem. 38, 691-695

34 Kohayashi, T., Shinnoh, N., Goto, I., Kuroiwa, Y., Okawauchi, M., Sugihara, G. and Tanaka, M. (1985) Biochim. Biophys. Acta 835, 456-464 